\title{
Responsibility and Mindset of Tourist and Community-Based Tourism Enterprise to Conserve the Environment and Energy
}

\author{
Sudjai Jirojkul ${ }^{1}$, Siwarit Pongsakornrungsilp ${ }^{2}$, Nontipak Pianroj ${ }^{3}$, \\ Prachyakorn Chaiyakot ${ }^{1}$, Narawadee Buakhwan ${ }^{4}$, M.S. Mia ${ }^{5}$, Kuaanan Techato ${ }^{1}$ \\ ${ }^{1}$ Faculty of Environmental Management, Prince of Songkla University, Hat Yai Campus,Thailand \\ ${ }^{2}$ The Center of the Excellence for Tourism Business Management and Creative Economy, \\ School of Management, Walailak University, Thailand \\ ${ }^{3}$ Faculty of Liberal Arts and Management Science, Prince of Songkla University, Surattani Campus, Thailand \\ ${ }^{4}$ College of innovation and management, Songkhla Rajabhat University, Thailand \\ ${ }^{5}$ School of Economics, Finance and Banking (SEFB), Universiti Utara Malaysia (UUM), \\ 06010, Sintok, Kedah, Malaysia
}

\begin{abstract}
The aim of the research is to assess the mindset, activities and the participation of communitybased tourism enterprises in the tourists' awareness and behavior. Tourism has the significant impact in order to develop the guideline for organizing the activities and managing the community-based tourism in reflecting the responsible environment and energy linking character and behavior of tourists. We found a strong growth mindset of entrepreneur's community as the key factor that affected on driving the participation of tourism management. Mindset was a significant mechanism to motivate and encourage sustainable tourism in the future. Finally, it represents the responsible environment and energy systematically.
\end{abstract}

Keywords - growth mindset, responsible tourism, community enterprise, tourism management and energy control.

DOI: 10.18421/TEM104-47

https://doi.org/10.18421/TEM104-47

Corresponding author: Kuaanan Techato,

Faculty of Environmental Management, Prince of Songkla University, Hat Yai Campus.

Email: siti.rohajawati@bakrie.ac.id

Received: 13 March 2021.

Revised: 26 October 2021.

Accepted: 01 November 2021.

Published: 26 November 2021.

(cc)BY-NC-ND (C) 2021 Sudjai Jirojkul et al; published by UIKTEN. This work is licensed under the Creative Commons Attribution-NonCommercial-NoDerivs 4.0 License.

The article is published with Open Access at www.temjournal.com

\section{Introduction}

If tourism is managed improperly and focused only on the financial aspects, it will affect the economy, society, and environment in the long-term. Moreover, managing without cooperation from all over sectors will result in ineffective management. In other words, since it is not started from point source of problem, the final solution then will brings many other problems such as the changes in traditional way of life and community culture, over dependence on tourism, highly increasing of competition in the community making people mind merely their own benefits than other and increasing of conflicts between groups [1], [2]. Additionally, increased energy used in the tourism sector causes carbon emission in the atmosphere [3]. Therefore, it can be indicated that the growth of tourism obviously affects the community and environment [4].

The management for sustainable tourism can serve purposes of Sustainable Development Goal (SDG's). As presented in $12^{\text {th }}$ goal: responsible consumption and production, $8^{\text {th }}$ goal: decent work and economic growth and $14^{\text {th }}$ goal: life below water [5]. To manage sustainable tourism, considering supply is needed by starting from tourism activities management, production of goods and service as well as employment. These are the main factors supporting the growth of tourism enterprises, which will bring valuable revenues to the community. In terms of demand or tourist, the important practice is to control their behavior not to harm the community and environment. Also, community-based tourism has to respond to the needs of visitors who would like to see more abundant nature and value of the environment [6]. Management of community-based tourism enterprises is considered as a key role to 
drive the community. It is a principle used as a tool to manage the natural resources, recover cultures, generate community's income, and exchange knowledge between travelers and community. Fundamentals of community based tourism are local ownership. That is to say, local people can manage the tourism and use tourism as the tool for enhancing the community involvement. People have an opportunity to share their ideas, jointly make a decision, take part in the process and get the benefits deriving from tourism [7]. Community collaboration encourages the strength of the community, people as the shared ownership of community and community empowerment [8]. Certainly, Community engagement can contribute their conceptual plan and tourism activities to the success.

In fact, the previous management of communitybased tourism seems opposite with its principal. To explain in detail, social and economic inequality has increased. Furthermore, when the community has achieved their goals, competition among them has then built up. For example, they cut prices or give more discounts on the products and services which are lower than its costs [2]. Lack of connection and marketing capacity lead the community to wait for outside supports or visitors walking into the areas. It is obviously seen that many communities turn to run the tourism business as the main work or more rely on tourism [2]. These situations have once happened in Tung Yee Peng, Lanta Island, Krabi province. Once they have tried to solve problems and learnt those obstacles to improve their community.

The main cause of increased weakness or vulnerability of the community-based tourism is the inefficient community development mechanism [9], incomprehensive plan made by community groups and ignorance of politicians or local governments regarding development on community-based tourism [10]. A study of Sin and Minca [1] stated that most troubles occurring in community-based tourism enterprises in Thailand were from the high level of corruption and egocentrism of entrepreneurs. They lacked of integrity and responsibility towards society and the environment. Promoting responsibility on only one business cannot reveal a clear picture of the tourism community. Collaboration in community can distinguish the responsibility of community. The proactive tourism business development will be noticeably disrupted or discontinuous because of economic factors and the personal selfishness. On the other hand, it may be a chance for a communitybased tourism enterprise to extend the positive mindset from a small to large group of people. Community can gather people who can represent the good responsibility with mindful mindset towards their environment, intently want to develop the community economy and known the importance of performing as tourism operator based on the value marketing strategy as well as the entrepreneurs who have to organize cultural activities, create a good experience and value awareness of good tourism towards travelers and hosts [11].

In another study Hafiz et al. [12], state that responsible tourism management is an appropriate strategy to develop a plan together in order to manage and improve product and marketing. It can be a scope for tourists' value awareness of community and promote the positive impact on economy, society and environment. It, furthermore, leads to sustainable tourism. Giving priority to tourism enterprises along with enhancing the value of tourism products and services is an interesting issue that the Ban Tung Yee Peng community should apply into the tourism management for final empirical results. The reasons for these actions are to demonstrate the intention to build up the unique tourism value and increase tourism opportunities for the community under the shared responsibility and develop the economy, culture and natural environment of the community. If community can achieve this management, it will be in line with Krabi's vision of 2014, which said, "International quality tourism city, sustainable industrial agriculture, livable society, and adaptable city".

Findings from study on Tung Yee Peng community-based tourism concerning both demand and supply sides would reduce certain "AttitudeBehavior Gap" [13]. Using the information collected from both sides, it conduced to the value co-creation of both producers and consumers according to the concept of Gronroos [14]. The level of consciousness and social behavior of tourists is based on the mindful consumption. Tourists' information was analyzed to develop the management approach concerning the perception of entrepreneurs in community-based tourism areas. Additionally, the other purposes were to push the tourism business forward to success by responding to the needs of tourists and raise the awareness of tourists together with tourism community at the same time.

\section{Literature Review}

\subsection{Tourist Behavior}

Dann [15] (1977) and Crompton [16] said that the travel behavior of tourists was generally based on two dimensions of push and pull factors which affected people's decision to visit some places instead of joining other activities. The push factor was from demand, motivation or their own internal forces that have not been fulfilled. The examples of motive were such as escaping from boring daily life, seeking relaxation and adventure, fulfilling prestige, and promoting a healthy life [17]. Likewise, the pull 
factor was about the external forces of destination attributes such as weather or climate, outstanding scenery, amenities and cheap fares [18]. Studying the motivation of Japanese tourists towards Thailand tourism of Sangpikul [2] displayed that there were three push motives found: looking for knowledge and new experiences, seeking relaxation, and completing ego-enhancement. On the other hand, there were four pull factors demonstrated: cultural and historical attractions, tourism facilities and management, entertainment and shopping as well as safe and clean destinations.

In terms of marketing, the concept relating to consumer behavior is S-R Theory (Stimulus Response Theory) [19]. The basic components of this concept are stimulus and response which will be expressed through consumer's purchase decision towards products or services. The stimulus comprises of marketing stimulus or marketing mix (4Ps) and other stimuli such as economy, technology, politics and culture. These stimuli will affect the individual characteristics and the consumer decision-making process, which is called "black box". It is the mindset of consumers which is notably different depending on each person. This "black box" is like a mindset according to the concept of mindful consumption. Besides, it gives an effect to the reaction or decision to buy such products and services. Decision-making process includes identifying the decision, gathering relevant information, evaluating the alternatives, taking action and reviewing purchase decisions (Figure 1).

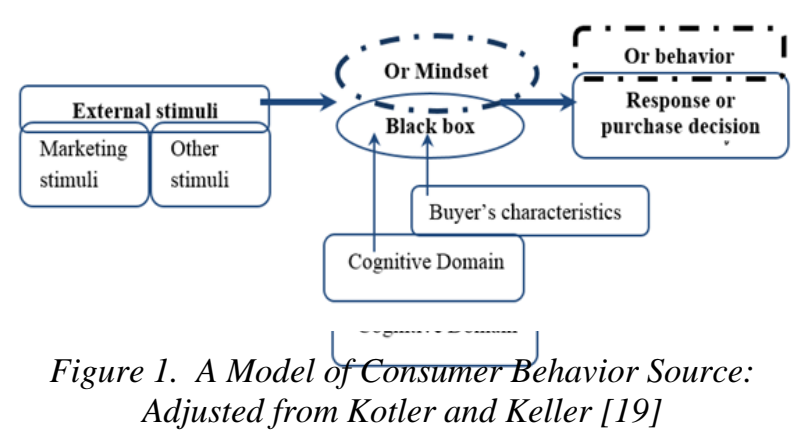

According to the research about behavior by Schwartz [20], it found that humans tended to demonstrate their behavior in a better way. Furthermore, from the point of view of environmentalists, they explained that humans have more sense and believe in the value of nature since they knew the current environmental impacts. Formerly, Schwartz has also proposed the normactivation theory. The principle of this norm is that humans will behave or change their behavior following their intended goals only when they are aware of what is right. The changed behavior was related to the consequences caused by value of things, perceived value, and personal norm. Success in behavioral change was due to stimulation of moral norms in the individual context. For example, people were encouraged by the ecological worldview. They realized that the valuable things were in critical condition. In addition, they had a self-awareness about impacts that might affect others. Consequently, the impact can be mitigated by changing the behavior or resolving the problem in order to prevent or restore the valuable things to a better one. This was based on the Value-Belief-Norm Theory of Stern's VBN, Dietz, and Kalof (1993). Referring to the research study of Wheale and Hinton $\lceil 21\rceil$ and Young et al [22], it supported that knowledge and perception related to the environment were important factors in enhancing purchase decisions on green products. Therefore, it demonstrated that ethical consumers could be seen when they changed their behaviors after they appreciated things or paid attention to the dangers arising from irresponsible actions, which affected the community and the environment.

\subsection{Responsible Consumption}

In fact, many resources in popular tourist attractions were often irresponsibly destroyed [23]. Tourism operators could solve this problem by defining the proper travel prototype in order to present the importance of tourist's responsible behavior towards society and the environment. This was also the starting point for responsible tourism that aimed to reduce the impact arising from tourism. Importantly, quality tourism could reduce the impact on society, environment and build up a strong tourism community [24]. The European Commission [25] has proposed eight guidelines for responsible tourism: (1) Seek for environmentally friendly tourism; (2) Select elaborately local accommodation where are close to nature; (3) Compare the destinations that are standard and supports sustainable development; (4) Build strong relationships to local community; (5) Spend on the affordable prices; (6) Respect labor standards; (7) Participate in business organizations; and (8) Create the transparency. In 2002 , there was a tourism conference held in Cape Town and they has announced the Cape Town Declaration regarding responsible tourism as follows: (1) Minimize negative impacts; (2) Generate greater economic benefits for local people; (3) Involve local people in decisions that affect their lives; (4) Conserve nature and cultural heritage; (5) Make positive contributions among local people and tourists; (6) Provides easily access to the tourist attraction and builds local pride and confidence to the community (World Tourism Market Responsible Tourism,). In 2008, the Tourism Authority of Thailand has promoted the 7 Greens policy, which consisted of Green Heart, Green Activity, Green Service, Green Community, Green Logistics, Green Attraction and Green Plus. This policy demonstrated the way of conducting activities friendly to the environment and not generating impact to the community. That would be the practices for tourism development and communitybased tourism enterprise that could promote the 
desirable tourist's attributes. In 2014, the Tourism Authority of Thailand initiated the policy to promote establishments and tourism enterprises for responsible tourism. They also supported entrepreneurs, individuals, groups, and public and private organizations to take part in conserving and restoring the environment in tourist attractions. The main purpose behind this policy was to show responsibility to society and the environment. The following were the examples of conducted activities; devoting time, effort, knowledge or money in the reforestation activity in order to increase the food sources for wildlife, absorb carbon dioxide, and reduce greenhouse gases; joining the environmental remediation and restoration activities in community or historic sites regarding waste management and wastewater treatment; applying the intellectual capital to develop the community capacity for sustainability of culture and environment; conducting project named "Be a Good Host" to raise awareness of being a good host as well as sustaining the ethical, safe, health-care and eco-friendly activities. Those mentioned activities were under the strategy for promoting the connectivity and participation in community directed by Office of Small and Medium Enterprises Promotion regarding the tourism industry field, 2012. Another example of an interesting campaign for socially responsible tourism was the project "Do \& Don't". This was promoted to tourists for inviting them to respect in the host's traditional culture and custom. In the result, they would behave properly and be a part of taking care of the environment in the admirable tourist attractions.

Next to the research of Goodwin and Francis [26], who especially focused on Niche Tourism Groups, we can add that the community was responsible for offering unique tourism products such as responsible experience, which has to relate to theory and practice of inner and outer-directed goals. The level of community involvement in responsible tourism needed to be show as the cultural identity of the community [27]. The study of corporate social responsibility in the hotel industry of Ratanajongkol [28] found that social responsibility in Thailand tended to be higher, especially in tourism. Corporate social responsibility of the hotel business remarkably fostered the hotel's reputation and convinced travelers to stay. Definitely, it led entrepreneurs to improve the activities and internal operations for sustainable tourism goals [29].

An example of a hotel that demonstrated social responsibility is Chumphon Cabana Hotel [30]. This hotel was operated based on the theory of sufficiency economy mixed with the socially responsible business practices. There were many projects concerning conservation activities and cooperating with the farmers living around the hotel. Hotel bought the agricultural products such as Leuang Pratew rice and local vegetables or fruits to be prepared as the raw materials used in their kitchen. They also created an eco-friendly product for the hotel use. Moreover, the water plants were grown in the sewage ponds to naturally treat wastewater. Furthermore, the cleaning products and biodiesel fuel were produced to use in the hotel. They also declared the policy not to drive a scooter or banana boat on the beach in front of the hotel in order to avoid obscuring the beautiful view of the beach, etc. Another hotel model is Tongsai Bay Hotel located in Samui Island, Suratthani. Here is a famous place which applied the Green policy in their operation. This made other hotel's entrepreneurs pay more attention to social responsibility. Referring to Samui Go Green project is another effective project enhancing green tourism by particularly community involvement and participation. Moreover, it created a balance between development of green island tourism together with the impressible image of a hotel. As a green tourism island, there were many important activities conducted such as activity for waste separating (using 3R principle), energy saving, nature conservation, using local natural products and wastewater treatment. These examples of business operations can be suitably adapted to the context of the tourism in community.

Benchmarking process was used as a good practice for effective water management. It was used as a model to save water and reduce wastewater generation for the hotels in Europe, Sweden and Queensland [31]. Launching marketing strategy in Greek hotel by focusing on developing an ecofriendly market with a shared vision and environmentally friendly technologies development led to energy management in tourism businesses, especially in the highlight issue of low carbon tourism [32]. These examples of responsible tourism activities significantly represented the positive impact to hotel business. As Porter and Kramer [33] supported that tourism especially emphasizing on social responsibility had the key strategy to gain a sustainable competitive advantage. Platform of responsible tourism included ethical sourcing, waste reduction and non-exploitative waste disposal, equitable employment, honest advertisement, fair pricing, community partnerships and responsible resource management.

The green activities can promote the monetary value of the business at the same time. Even social responsibility activities increased organization expenses, but they still considered social responsibility as a usable strategy that would give positive impact in the long run. Effective communication between organization and community regarding social and environmental issues could also resolve the conflicts in tourism. Moreover, there were other activities that did not have a direct profit to the hotel business such as 
donations to the community, and social and environmental communication. Eighty percent of leading hotels focused on providing donations to locals, setting a budget and determining their vision towards social responsibility, but they did not mention the environmental problem. Referring to the study of Panitha and Mohd Rassi [34] about Malaysian hotel business showed that Greenwashing strategy was used as a way of providing misleading information about how a company's products are more environmentally sound to green consumers in order to react to green claims requested by visitors. However, this action could be compared as every coin has two sides. It was surely better than doing nothing.

Responsible tourism management is an appropriate strategy in developing a work plan, product and marketing [12]. It supported tourists to perceive the community's value. Accordingly, the community would have the ability to productively manage tourism based on solving social and environmental problems. It would also be a marketing channel that created values of products and services. Indeed, consumers would have a better and happier life. According to Kotler [35] report, the importance or core of marketing work was the art of delivering quality, service and value to customers. This was also confirmed by a study of Goodwin and Francis [26] about responsible and ethical tourisms, which were the popular marketing principle in England. These concepts of tourism expressed that consumer's attitudes increased with their willingness to pay up to 7\% within two years (1999-2001).

Undoubtedly, the responsible tourism was trendier as well.

\section{Methodology}

This research studied both quantitative and qualitative parts. The first part focused on tourists. Since tourists are important factors of tourism that has to be managed, controlled and modified to the right mindset in order to prevent and reduce negative impacts that may occur on society and environment caused by inappropriate tourism activities or tourists' behavior. The first part of the study therefore aimed to investigate the mindset and behavior of tourists. 400 questionnaires were distributed to tourists visiting the Ban Tung Yee Peng community in order to collect data from them regarding the demand in mindful consumption principles [18]. Mindful mindset is characterized by a sense of caring for self, for community, and for nature. Paying attention into these elements will influence in controlling and changing behavior into mindful behavior. Moving to the part of qualitative research, this part is related to studying and analyzing the local tourism management. The study area was community-based tourism at Ban Tung Yee Peng, the Lanta Island, Krabi. Interviewing key informants about the concept of tourism management, local events organization and community participation [36], was conducted. The collected data were analyzed to find out the appropriate guidelines for responsible tourism management of the community in line with the tourists' awareness. The research offered two aspects: tourists and community-based tourism enterprise. They both were the key role taking part in the tourism system of Tung Yee Peng area. The aim was to make the shared values of these two groups involving in sustainable tourism management in the future.

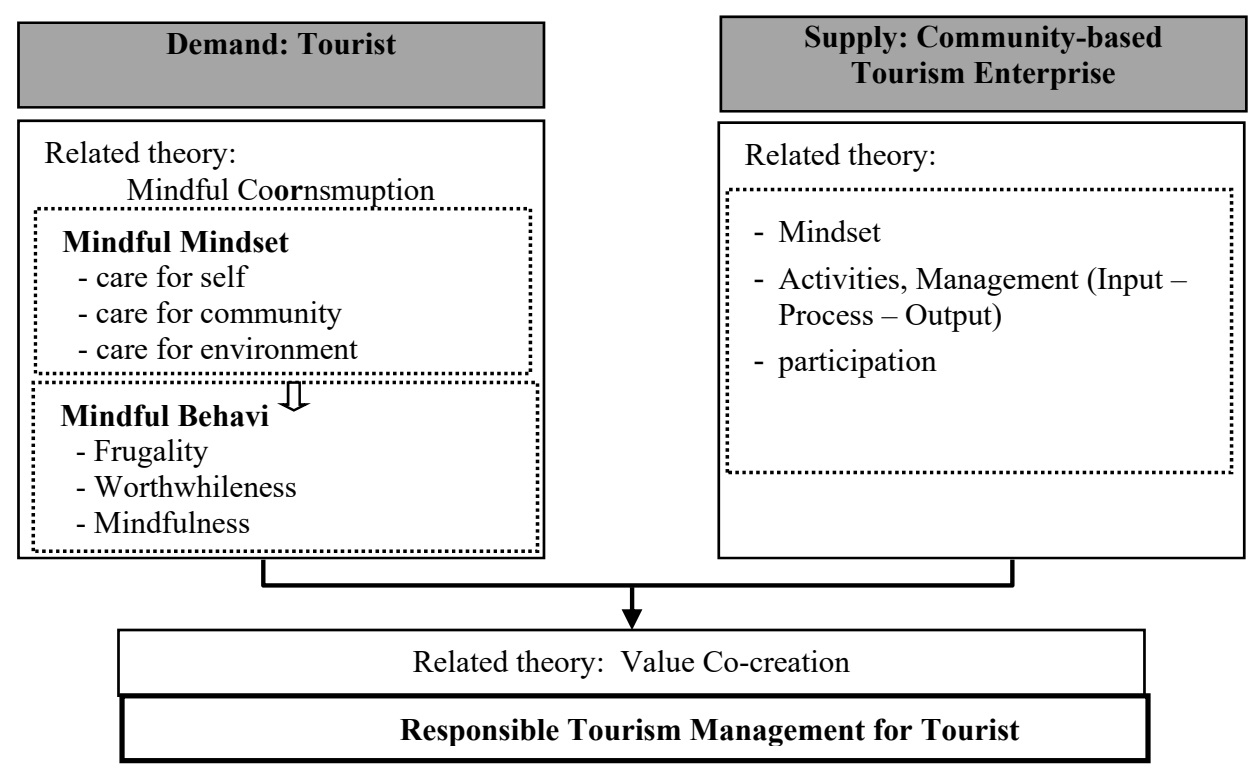

Figure 2. Research concept 


\section{Results and Findings}

\subsection{Demographic Profile}

A quantitative study was conducted by collecting sample data from tourists in Tung Yee Peng village, the Lanta Island, Krabi Province. There were 52\% female and $48 \%$ male. The average age of them was at 33.8 years old. The minimum age was 15 years old while the highest age was at 82 years old. Most of them were employee and students. In addition, 49.8 percent of them came from Europe and 27.0 percent were from Scandinavia.

\subsection{Mindful Mindset of the Tourist}

The mindful mindset of tourists was represented at the high and highest level. Mindset that represented the highest average was about the need of tourists which they admired the local cultures and their way of

Table 1. General information life (mean 4.50), following by the tourists perceived and understood the values of the natural environment $($ Mean $=4.32)$ and community lifestyle as well as local wisdoms as a tool for preserving natural resources (mean $=4.31$ ). In addition, the lowest mean was about tourism can conserve the local culture and way of life (Mean $=3.51)$.

\subsection{Mindful Behavior of Tourist}

The behavior that tourists gave the highest average was no littering, not scratching on the tree, cave walls or archaeological sites (mean $=4.44,4.42$, 4.40), following by reusing and recycling objects before throwing them as waste (Mean $=4.26$ ). The topic that tourist placed the lowest average was about showing others that they were engaged in environmental care and conservation through product usage behavior $($ Mean $=2.07)$.

\begin{tabular}{|c|c|c|c|c|c|c|c|c|}
\hline Gender & $\begin{array}{l}\text { Male } \\
52.0 \%\end{array}$ & $\begin{array}{c}\text { Female } \\
48.0 \%\end{array}$ & & & & & & \\
\hline \multirow[t]{2}{*}{ Age } & $15-25$ & $26-35$ & $36-45$ & $46-55$ & $\begin{array}{c}\text { More than } \\
56\end{array}$ & & & \\
\hline & $31.8 \%$ & $29.5 \%$ & $20.8 \%$ & $\begin{array}{c}12.0 \% \\
\text { in }=15, \mathrm{Max}=8\end{array}$ & $3.8 \%$ & & & \\
\hline \multirow[t]{2}{*}{ Occupation } & Student & $\begin{array}{l}\text { Freelance, } \\
\text { Contractor }\end{array}$ & Housewife & $\begin{array}{l}\text { Agriculturist, } \\
\text { Fisherman }\end{array}$ & Employee & $\begin{array}{c}\text { Government } \\
\text { officer, State } \\
\text { enterprise officer }\end{array}$ & $\begin{array}{c}\text { Business } \\
\text { owner }\end{array}$ & $\begin{array}{l}\text { Retirement } \\
\text { age }\end{array}$ \\
\hline & $20.5 \%$ & $9.3 \%$ & $4.0 \%$ & $0.5 \%$ & $36.0 \%$ & $5.5 \%$ & $9.0 \%$ & $15.3 \%$ \\
\hline \multirow[t]{2}{*}{$\begin{array}{l}\text { Current } \\
\text { address }\end{array}$} & Scandinavia & Europe & American & Africa & Australia & Asia & $\begin{array}{c}\text { Thailan } \\
\text { d }\end{array}$ & \\
\hline & $27.7 \%$ & $51.1 \%$ & $8.9 \%$ & $0.8 \%$ & $2.8 \%$ & $3.8 \%$ & $4.9 \%$ & \\
\hline
\end{tabular}

Table 2. Mean, Standard deviation, meaning of mindful mindset

\begin{tabular}{|c|c|c|c|c|}
\hline & Mindful Mindset & Mean & S.D. & Meaning \\
\hline \multirow{2}{*}{ Responsible for self } & Perceive and understand value of nature. & 4.32 & 0.777 & Highest \\
\hline & Healthy and strong mind. & 4.27 & 0.668 & Highest \\
\hline \multirow{8}{*}{$\begin{array}{l}\text { Responsible for } \\
\text { community }\end{array}$} & $\begin{array}{l}\text { When visiting the community, the tourist should } \\
\text { respect its cultures and way of life. }\end{array}$ & 4.5 & 0.668 & Highest \\
\hline & $\begin{array}{l}\text { Tourism creates jobs and income for the community } \\
\text { and improves their livelihood }\end{array}$ & 4.24 & 0.816 & Highest \\
\hline & Impression on community participation. & 4.01 & 0.812 & High \\
\hline & $\begin{array}{l}\text { Travelling brings friendships and chance to meet the } \\
\text { new friends. }\end{array}$ & 3.95 & 0.910 & High \\
\hline & Mass tourism impairs community way of life. & 3.89 & 1.010 & High \\
\hline & $\begin{array}{l}\text { Tourism builds pride and self-esteem among the } \\
\text { locals. }\end{array}$ & 3.71 & 1.013 & High \\
\hline & $\begin{array}{l}\text { Tourism strengthens the community and builds unity } \\
\text { among the locals }\end{array}$ & 3.67 & 1.012 & High \\
\hline & $\begin{array}{l}\text { Tourism conserves cultures and lifestyles of the } \\
\text { locals. }\end{array}$ & 3.51 & 1.161 & High \\
\hline \multirow{3}{*}{ Responsible for nature } & $\begin{array}{l}\text { Local life and local wisdom are a tool to sustains } \\
\text { natural resources. }\end{array}$ & 4.31 & 0.803 & Highest \\
\hline & $\begin{array}{l}\text { Plenty natural resources are valuable factors for living } \\
\text { and are the food source in a community. }\end{array}$ & 4.24 & 0.828 & Highest \\
\hline & $\begin{array}{l}\text { Plenty natural resources can absorb toxic that is } \\
\text { dangerous for lives }\end{array}$ & 3.90 & 1.057 & High \\
\hline
\end{tabular}


Table 3. Mean, standard deviation, meaning of mindful behavior

\begin{tabular}{|c|c|c|c|c|}
\hline & Mindful Behavior & Mean & S.D. & Meaning \\
\hline \multirow{4}{*}{$\begin{array}{l}\text { Reduce selfish desire, } \\
\text { Frugal consumption }\end{array}$} & $\begin{array}{l}\text { Community way of life is a good example of frugal } \\
\text { consumption and simple ways of living. }\end{array}$ & 3.85 & 0.845 & High \\
\hline & I have reduced the use of unnecessary products. & 3.83 & 0.934 & High \\
\hline & $\begin{array}{l}\text { A tourist changes attitudes towards consumption } \\
\text { and uses natural resources economically. }\end{array}$ & 3.82 & 0.934 & High \\
\hline & Tourism is a cause of energy consumption & 3.38 & 1.212 & Medium \\
\hline \multirow{3}{*}{$\begin{array}{l}\text { Reduce using a single- } \\
\text { use products, Efficient } \\
\text { use }\end{array}$} & $\begin{array}{l}\text { Reusing and recycling to add value to objects } \\
\text { before they become wastes. }\end{array}$ & 4.26 & 0.788 & Highest \\
\hline & $\begin{array}{l}\text { The use of reused and recycled products brings } \\
\text { economic enrichment to a community. }\end{array}$ & 4.14 & 0.829 & High \\
\hline & I have used more recycled products. & 3.84 & 0.954 & High \\
\hline \multirow{15}{*}{$\begin{array}{l}\text { Mindful consumption, } \\
\text { Refuse competition in } \\
\text { consumption trends }\end{array}$} & I do not litter. & 4.44 & 0.746 & Highest \\
\hline & $\begin{array}{l}\text { I do not write on the trees, caves as well as } \\
\text { archaeological sites. }\end{array}$ & 4.42 & 0.720 & Highest \\
\hline & I do not stand on corals. & 4.40 & 0.736 & Highest \\
\hline & $\begin{array}{l}\text { Touring by bicycle makes a tourist close to nature and } \\
\text { breath fresh air. }\end{array}$ & 4.19 & 0.85 & High \\
\hline & $\begin{array}{l}\text { A tourist with temperance is considered having } \\
\text { social maturity appropriate for different situations } \\
\text { and conditions. }\end{array}$ & 4.13 & 0.799 & High \\
\hline & $\begin{array}{l}\text { Being close to nature makes me use more eco- } \\
\text { friendly products. }\end{array}$ & 4.03 & 0.982 & High \\
\hline & $\begin{array}{l}\text { Before buying a product, one needs to compare its } \\
\text { quality and benefits with its price. }\end{array}$ & 3.99 & 0.908 & High \\
\hline & $\begin{array}{l}\text { Community-based tourism makes me care for } \\
\text { surroundings more. }\end{array}$ & 3.96 & 0.838 & High \\
\hline & $\begin{array}{l}\text { I prefer visiting a travel destination where } \\
\text { environment and society are the main concern to } \\
\text { visiting a travel destination full of conveniences } \\
\text { and facilities. }\end{array}$ & 3.93 & 0.919 & High \\
\hline & $\begin{array}{l}\text { I consider impacts on environment before buying a } \\
\text { product, i.e. material and manufacturing process } \\
\text { that is friendly to environment. }\end{array}$ & 3.87 & 0.908 & High \\
\hline & $\begin{array}{l}\text { Having seen plenty natural resources, including } \\
\text { marine life, wildlife and mangrove forests, I would } \\
\text { like to be part of natural resource conservation. }\end{array}$ & 3.82 & 1.031 & High \\
\hline & $\begin{array}{l}\text { I have bought more products that are made from } \\
\text { natural materials, produced by a community, and } \\
\text { eco-friendly. }\end{array}$ & 3.80 & 0.999 & High \\
\hline & $\begin{array}{l}\text { Having seen negative impacts on a community and } \\
\text { environment, I have used more second-hand } \\
\text { products in order to make the best use of them and } \\
\text { help reducing the impacts. }\end{array}$ & 3.62 & 1.085 & High \\
\hline & A tourist reduces unnecessary expenses. & 3.49 & 1.048 & High \\
\hline & $\begin{array}{l}\text { Using reused or recycled products adds value to a } \\
\text { person and shows to the public that he/she is } \\
\text { engaged in environmental care and preservation. }\end{array}$ & 2.07 & 0.956 & Low \\
\hline
\end{tabular}

\subsection{Analysis on Conceptual Framework Towards Management of Community Enterprise}

Referring to the interview with the group leader, committee members and related stakeholder such as tourism operators and tourism group members to gather information about people's mindsets toward successful collaboration at the community level, participation and joining in responsible social, energy and environmental activities, it was found that the goal behind people participating in community tourism activities was to effectively conduct tourism activities for both individual and community's benefits. The individual benefit referred to supporting their own and neighbor business more successful. Everyone was hired and gained more income for supporting their livelihood and family. They were independent and there was no debt. Next to the aspect of community benefit, when there were more jobs created in the local community, it could 
increase the employment requirement. People who once moved out from their hometown to work in other areas would have the opportunity to return back to the community and young people did not need to leave their children behind with their parents. Also, they could spend time taking care of the family. This would promote the harmony in relationships among family members.

In the morning and afternoon, the group discussion was always seen at the local coffee house. The main objective of discussion was to find the solutions for problems arising in community tourism groups. Even, sometimes, some arguments occurred, it made a better change. This was not only a good chance for exchanging the opinion, but also able to cease the conflict among different groups of people. Tourism groups could draw a working age population to participate in the community tourism development. The strength of these kinds of people was their powerful energy. They also had positive thinking and efficient creativity. When more people with the same interest were formed in a group, work tasks were clearly distributed to each person according to their specialization. Business rules, guidelines for taking care of tourists and regulation for mangrove management then were established. Surely, it made working in groups systematic and progressive.

A creative mindset of the community leader that sincerely conveyed to community's members was represented here below.

"An important point that can change people's mindset is giving people time to review themselves. There is no one who can change others if that person is not aware and grabs their own chance. The main role of a leader is being a good base for them.

"We need to walk by ourselves before asking help from other"

"Our goal is when we gain more income and we can be more responsible for society."

An overall mindset of people in the community was a growth mindset concerning the medium- and long-term future. It represented how the tourism community could achieve the goal together and how to pass these positive activities to support their descendant's livelihood in the future. If everyone was independent, they would support their community and willingly help other people. Finally, the community would become an independent community which was able to create a stable economy for generations to generations. Also, the community could take care of the environment completely for a sustainable future.

Participation in community-based tourism enterprise was considered as the management by a small group for the large group of people. The major role of committees was to operate the activities and design the policy in community-based tourism enterprises. Meanwhile, some other members could give feedback and most of the members could listen to, support and participate in provided activities or observe working in the group. According to the interview, the good participation is to stay away from any interruption. If the resolution of the group was displayed, the rest of members should be glad and willingly perform following that conclusion. "They have more knowledge, so they can take us to a good future." This message showed the growth mindset that people firmly believe in team. This would build a community engagement to work and help each other and succeed in the expected point. The working process of Ban Tung Yee Peng community for being a "Green" community was in line with the national policy that was given for Krabi Province. They determined the word "Green" as "Quality Tourism". Therefore, Ban Tung Yee Peng has defined their community vision as "Green Step Village". Many entrepreneurs, employees (tour guide and boat driver) or queue maker said similarly that "Most visitors were so serious about the environment. Some of them did not leave the cigarette butts on the sea or boat. Moreover, they always kept it into their bag before throwing away appropriately only when they arrived on the shore". Thus, this caused people to spread word of mouth about the importance of nature and environment. Since tourists, as the customer, came to buy the service from the community and they significantly paid attention to environmental issues, people in the community must therefore deal with tourist behavior and respond suitably to their needs. Tourist habits then played an important role in motivating tourism enterprise to a responsible environment.

Regarding activities management, the community has initiated various activities that provided widely benefit to local people covering the aspects of their way of life and environment. That would promote the growth of tourism in the community. The list of conducted activities was presented as follows:

1. Environmental activity: Since the important local resource Ban Tung Yee Peng was the mangrove forest covering over 1,995 rai where it was taken care by local people under the direction of the Department of National Parks, Wildlife and Plant Conservation. This mangrove forest was compared as a big source of carbon absorbers by its trunk and sediment. At the estuary, there were also sea grasses. The community tourism enterprise has continuously proceeded on the environmental conservation activities until they received the award for "People save forest, forest save community" in 2017. Community received the trophy from Her Royal Highness Princess Maha Chakri Sirindhorn as well. Environmental tourism activities included planting mangrove forests, building a fish house, taking a gondola ride to see 
mangrove tunnels and fishermen daily life. This gondola was once built imitating from coal-fired boats which was normally used in the community in the past. Since it could be driven without using fuel, it did not cause the air-pollution later. Another activity was referred to improving the home area and continuously keeping the community clean.

2. Activities related to the local people's lifestyle: making fish curry paste, growing vegetables for eat and sell, joining cooking activities and enjoying eating local food with the community members, going on a fishing boat to study the fishermen life, and staying at a homestay to learn the people's culture.

3. Joining the projects that offered the extra income: local product shops, restaurants, souvenir shops: shrimp paste made in Lanta Island, fresh seafood, dried seafood (Talabeng shop, Kaeng Som shop), clothes, bags and souvenirs from Ban Tung Yee Peng.

The procedure for setting these activities based on using fresh local resources, reducing energy consumption in transportation and storage, reducing the use of chemicals and using eco-friendly packaging or reusable containers only. All processes focused on the use of local people's indigenous knowledge and simple technology available in the community. It was not only the way to save the cost, but also support local people's ability. These activities promoted a good relationship among people in the community and also provided the community with great income and recognition towards the importance of their traditional lifestyle. They could spend their lives the same while getting more revenue. In terms of tourists, they were satisfied at the highest level. Tourists felt relaxed and enjoyed seeing the simple lifestyle of the community. When they were impressed with tourism activities organized by the community, they would come back again. They also shared that impression to their friends and through social media which would greatly expand the market for the community-based tourism enterprise to be more well known.

\section{Conclusion}

Tourists who came to visit Ban Tung Yee Peng community emphasized on giving respect to local culture, livelihood and abundant nature. They were concerned about littering, efficient use of resources, reusing and recycling things before it became waste. This implicated that visitors have a good awareness and behavior when travelling. Underneath their mindful mindset, they cared for the community and the environment and looked forward to seeing the natural and socio-cultural authenticity. They were ready to take part in caring for the community and the environment in every destination. The tourist also gave the open-question that they were quite concerned and worried about the garbage problem in the area. They suggested that the administrative sector or policy maker should pay more attention to environmental management more than focusing on developing infrastructure or seeking for a new landmark.

The beliefs and determination of people played a vital role in mindset developing. The mindset of people in the community-based tourism enterprise could be called the growth mindset developed with their strong belief and hope. They believed that if a tourism community happened, the quality of life would be improved. With the mentioned reason, people in the community then strived over many obstacles and tried to pass through the hardness in order to improve their mindset.

According to the study of responsible tourism management of Ban Tung Yee Peng, it revealed a responsibility at community level that could operate by itself based on the resources available in the community. The community management was under the systematic management principles which included 1) Input of raw materials produced in the community and environmentally friendly products; 2) Simple management process that easily operate by community and minimize impact on the environment such as reducing, reusing, and recycling process. Local wisdom has been used basically for producing the innovation based on Corporate Social Responsibility process (CSR-process). The output obtained from the operation including products, services and tourism activities that will reduce the impact on the community and environment. This created a corporate social marketing together with marketing value in tourism products and services according to the needs of tourists. The social responsibility of the Tung Yee Peng communitybased tourism enterprise was based on the mindful mindset and mindful management for tourist, community, environment and energy in order to manage sustainable tourism in Tung Yee Peng community.

In community partnerships, there would sometimes be conflict arising. The way to harmonize people's relationships was equally giving them opportunities to exchange their opinions to get a consensus of the group. The argument, regularly, has shown in the meeting including the local coffee house. This was consistent in Longino [36] study that discussion in group to exchange the ideas and opinion can reduce serious incidents, make comprehension of each other and reduce the role of some influential person behind the group. In the result, they would make a good understanding in communities and believe in cooperation in the future because they had the 
opportunity to open-mind sharing and solve the conflicts with each other. Organizing a tourism management system including all aspects of product and service development, management for reducing energy consumption and environmental impact and encouraging tourists to recognize the value of the community were based on the concept of Hafiz et al. [12]. According to the tourism management of Ban Tung Yee Peng community has shown that there was still an authentic tourism context represented since the local people still kept working as coastal fisheries and mainly depending on nature and they lived as the simple traditional way. The natural and authenticity of this community could convince tourists to visit the Tung Yee Peng area. According to abundant mangrove conservation in the community, it was a factor in attracting a special group of tourists (niche) who admired the values of the naturalness to the community. This was in accordance with the study of Shaw and William [37] and Pongsakornrungsilp [38] that communities needed to have a viewpoint for tourism management, especially for tourists who valued on subjective things and responsible environment [4]. Conclusively, this is the best way to make worthy experience between tourists and communities in order to develop the growth mindset of each other.

\section{Acknowledgement}

This research was supported by Grant Number ENV6402012 N from Prince of Songkla University.

\section{References}

[1]. Sin, H. L., \& Minca, C. (2014). Touring responsibility: The trouble with 'going local'in community-based tourism in Thailand. Geoforum, 51, 96-106.

[2]. Kontogeorgopoulos, N., Churyen, A., \& Duangsaeng, V. (2015). Homestay tourism and the commercialization of the rural home in Thailand. Asia Pacific Journal of Tourism Research, 20(1), 29-50.

[3]. Chen, L., Thapa, B., \& Yan, W. (2018). The relationship between tourism, carbon dioxide emissions, and economic growth in the Yangtze River Delta, China. Sustainability, 10(7), 2118.

[4]. Noypayak, W. (2008). Value dimensions of Thailand as perceived by UK tourists. (Doctoral dissertation, Ramkhamhaeng University).

[5]. United Nation. (2018). Envision2030: 17 goals to transform the world for persons with disabilities. Retrieved from:

https://www.un.org/development/desa/disabilities/env ision2030.html [accessed: 14 February 2021].

[6]. Hudson, S. (2008). Tourism and Hospitality Marketing: A Global Perspective. Sage.
[7]. Kayat, K., Ramli, R., Mat-Kasim, M., \& AbdulRazak, R. (2014). Community-based rural tourism as a sustainable development alternative: An analysis with special reference to the community-based rural homestay programmes in Malaysia. Theory and Practice in Hospitality and Tourism Research, 223.

[8]. Iorio, M., \& Corsale, A. (2014). Community-based tourism and networking: Viscri, Romania. Journal of Sustainable Tourism, 22(2), 234-255.

[9]. Epler Wood, M. (2005). Stepping up: Creating a sustainable tourism enterprise strategy that delivers in the developing world. Epler Wood Report (October). EsplerWood International, downloaded at www. eplerwood. com. Accessed, 24(9), 2007.

[10]. Kaján, E. (2014). Arctic tourism and sustainable adaptation: Community perspectives to vulnerability and climate change. Scandinavian Journal of Hospitality and Tourism, 14(1), 60-79.

[11]. Jamal, S. A., Othman, N. A., \& Muhammad, N. M. N. (2011). Tourist perceived value in a communitybased homestay visit: An investigation into the functional and experiential aspect of value. Journal of Vacation Marketing, 17(1), 5-15.

[12]. Hafiz, M., Jamakuddin, M. R., Zulkifly, M. I., and Othman, N. (2014). Exploring responsible tourism development facet. In Theory and practice in hospitality and tourism research - proceeding, International Hospitality and Tourism Conference. $2^{\text {nd }}$, Penang; Malaysia; 2-4 september 2014.

[13]. Young, W., Hwang, K., McDonald, S., \& Oates, C. J. (2010). Sustainable consumption: green consumer behaviour when purchasing products. Sustainable development, 18(1), 20-31.

[14]. Grönroos, C. (2011). Value co-creation in service logic: A critical analysis. Marketing theory, 11(3), 279-301.

[15]. Dann, G. M. (1977). Anomie, ego-enhancement and tourism. Annals of tourism research, 4(4), 184-194.

[16]. Crompton, J. L. (1979). Motivations for pleasure vacation. Annals of tourism research, 6(4), 408-424.

[17]. Kim, S. S., \& Lee, C. K. (2002). Push and pull relationships. Annals of tourism research, 29(1), 257260.

[18]. Klenosky, D. B. (2002). The "pull" of tourism destinations: A means-end investigation. Journal of travel research, 40(4), 396-403.

[19]. Keller, K. L., \& Kotler, P. (2012). Branding in B2B firms. In Handbook of business-to-business marketing. Edward Elgar Publishing.

[20]. Schwartz, S. H. (1977). Normative influences on altruism. In Advances in experimental social psychology (Vol. 10, pp. 221-279). Academic Press.

[21]. Wheale, P., \& Hinton, D. (2007). Ethical consumers in search of markets. Business Strategy and the Environment, 16(4), 302-315.

[22]. Oates, C., McDonald, S., Alevizou, P., Hwang, K., Young, W., \& McMorland, L. A. (2008). Marketing sustainability: Use of information sources and degrees of voluntary simplicity. Journal of Marketing Communications, 14(5), 351-365. 
[23]. Bach, M. P., Zoroja, J., \& Merkac-Skok, M. (2014). Social responsibility in tourism: system archetypes approach. Kybernetes: The International Journal of Systems \& Cybernetics, 43(3-4), 587-600.

[24]. Becken, S., Mahon, R., Rennie, H. G., \& Shakeela, A. (2014). The tourism disaster vulnerability framework: An application to tourism in small island destinations. Natural Hazards, 71(1), 955-972.

[25]. European Commission. (2008). Corporate Social Responsibility (CSR): Guidelines CSR-Reporting in tourism. Germany: KATE-Center for ecology \& development.

[26]. Goodwin, H., \& Francis, J. (2003). Ethical and responsible tourism: Consumer trends in the UK. Journal of Vacation Marketing, 9(3), 271-284.

[27]. Caruana, R., Glozer, S., Crane, A., \& McCabe, S. (2014). Tourists' accounts of responsible tourism. Annals of Tourism Research, 46, 115-129.

[28]. Ratanajongkol, S., Davey, H., \& Low, M. (2006). Corporate social reporting in Thailand: The news is all good and increasing. Qualitative Research in Accounting \& Management., 3(1), 67-83.

[29]. Ryan, C. (2002). Equity, management, power sharing and sustainability-issues of the "new tourism'. Tourism management, 23(1), 17-26.

[30]. Inoue, Y., \& Lee, S. (2011). Effects of different dimensions of corporate social responsibility on corporate financial performance in tourism-related industries. Tourism Management, 32(4), 790-804.
[31]. Warnken, J., Bradley, M., \& Guilding, C. (2005). Eco-resorts vs. mainstream accommodation providers: an investigation of the viability of benchmarking environmental Management, 26(3), 367-379.

[32]. Can, H., \& Hongbing, D. (2011). The model of developing low-carbon tourism in the context of leisure economy. Energy Procedia, 5, 1974-1978.

[33]. Porter, M. E., \& Kramer, M. R. (2006). Strategy and society: the link between corporate social responsibility and competitive advantage. Harvard business review, 84(12), 78-92.

[34]. Punitha, S., \& Rasdi, R. M. (2013). Corporate social responsibility: Adoption of green marketing by hotel industry. Asian Social Science, 9(17), 79.

[35]. Kotler, P. (2003). Marketing insights from A to Z: 80 concepts every manager needs to know. John Wiley \& Sons.

[36]. Longino, H. E. (1996). Cognitive and non-cognitive values in science: Rethinking the dichotomy. In Feminism, science, and the philosophy of science (pp. 39-58). Springer, Dordrecht.

[37]. Shaw, G., \& Williams, A. M. (2004). Tourism and tourism spaces. Sage.

[38]. Pongsakornrungsilp, S., \& Schroeder, J. E. (2011). Understanding value co-creation in a co-consuming brand community. Marketing Theory, 11(3), 303-324. 